gorilla. As regards the mandible, comparison is difficult, owing to the imperfect state of the Australopithecus mandible. Differences, however, from that of chimpanzee and gorilla are to be noted as well as resemblances to juvenile Sinanthropus.

The two mandibles of special importance in view of their rivalry with Sinanthropus on the score of antiquity, are Heidelberg and Piltdown. In regard to Piltdown, Prof. Weidenreich reaffirms his previously expressed inability to accept this jaw as that of a human being. To accept it, he maintains, would imply that in England lived a hominid with the brain case of recent man and an anthropoid-like jaw, while at the same time there was in the Far East another human being with the most primitive brain known hitherto, and a jaw distinctly more closely related to that of recent man than to that of the chimpanzee. The Piltdown jaw, in fact, as has been demonstrated by H. F. Friederichs, approaches most nearly the jaw of an orang, and no direct comparison between it and the mandible of Sinanthropus is possible. Piltdown does not come within the line from which Sinanthropus was derived, but belongs to the highly specialized group orang, chimpanzee, gorilla-forms removed from the human line.

With regard to the Heidelberg mandible, the antiquity of this has been called into question, but on the other hand the Steinheim skull has been considered to belong to the third Riss-Wiurm interglacial or even earlier. Yet it approaches recent man more nearly than does the Neanderthal type. The general conclusion seems to be valid that the geological antiquity of hominid finds in Central Europe does not guarantee morphological primitiveness. The high geological age claimed for the Heidelberg find does not decide anything in regard to its phylogenetic precedence. The teeth of Heidelberg show none of the pithecoid characters which mark Sinanthropus, though the latter is of about the same age. In Heidelberg man, small teeth are combined with a bulky jaw which is no sign of primitiveness. None of its distinctive features, to which attention has been directed, are really a mark of primitiveness.

Of the Neanderthal mandibles, the Ehringsdorf adult is closest to Sinanthropus.

On the general evolutionary problem, the evidence of the Sinanthropus mandible points to the conclusions : that Peking man is a direct forerunner of recent man ; that only a general line which human evolution follows can be traced to a remote destination, and that regressive and progressive factors are to be found in every fossil mandible to a certain extent; that Sinanthropus does not represent a 'specialization', and that certain characters which may be regarded as a mark of primitiveness are found associated in the Sinanthropus mandible; and that the development of certain other characters such as the beginning of development of a mental trigonum, makes it quite possible that Peking man may have possessed the faculty of speech, as many indications in his cultural life appear to suggest.

\title{
Science Masters Association
}

\section{Annual Meeting}

\begin{abstract}
$\mathrm{T}$ HE thirty-serenth annual meeting of the Science Masters Association was held on January 5-8 in Manchester. Only once before has the Association been north of Birmingham for its meeting, and never before to Manchester, but the generous activity of the host-the University of Manchester-and vigorous efficiency of the local committee, provided one of the most thoroughly satisfying meetings the Association has ever had. There were as usual exhibitions by leading publishers and manufacturers of scientific apparatus; there were demonstrations by the University science departments, and a particularly complete exhibition at the College of Technology, whither the whole meeting was bodily transferred by bus for one evening ; and an unusual feature for a provincial meeting was the members' exhibition, never before held outside London.

The president for the year was the Vice-Chancellor of the University of Manchester, whose presidential address was as happy in delivery as it was penetrating in substance. He reminded his audience that the university teacher of medicine, himself a specialist, must train men so that all may have the general grounding which makes the good 'general practitioner', and yet so that the ten per cent who are to be specialists may have a proper foundation for their work; and noted a parallel with the task of the science master, who must use his specialist knowledge to train the ninety per cent of citizens as well as the ten per cent of technicians. He pleaded for an early
\end{abstract}

study of living things and their interdependence, even at the expense of the exact sciences, recalling the unique appeal of biology and its humanizing and broadening influences. He also expressed the hope that universities and schools would soon find an escape from a position in which each accused the other of fostering early specialization. It is for the teacher a peculiar merit of biology that it is not a science where control is simple or laws easy to arrive at; thus it affords a link between the physical sciences and ordinary life.

Other lectures, and the demonstrations arranged in the University science departments, were generally relevant to the recent research work going on in the University. Prof. W. L. Bragg demonstrated methods and results of erystal-structure investigation, and Mr. R. W. James, to whom the Association was able to offer the first public congratulations on his election to the chair of physies at the University of Cape Town, lectured on "The Architecture of Solid Matter". Prof. D. R. Hartree demonstrated the differential analyser. Perhaps the most popular exhibition was in the Chemistry Department, where Dr. G. N. Burkhardt had arranged a comprehensive series of demonstrations of recent spectroscopic work on vitamins and carotene. Prof. I. M. Heilbron, speaking on "Modern Technique in Biochemistry", showed how by colour separation and distillation it is possible to separate nearly-related substances in minute quantities; vitamin $\mathrm{D}_{3}$ has thus been isolated, and vitamin A nearly so. 
Prof. T. H. Pear educated and entertained a large audience concerning "The Borderland between Physies and Psychology"; he convicted of error any who still believed in the reliability of their senses, and considered how far psychology might dare to use the methods of the older sciences. Biologists found much of special interest to them at the meeting; in addition to demonstrations in the Botany and Zoology Departments dealing with genetics, ecology, the biology of injurious insects and pest-control in practice, there were lectures by Prof. H. Graham Cannon on "The Mechanics of CellDivision" and by Prof. J. Montagu Drummond on "Some Practical Applications of Botanical Seience".

There was a large attendance at a discussion on the Association's recent report on the "Teaching of General Science". The president took the chair, and Mr. C. L. Bryant (Harrow), chairman of the subcommittee which drew up the report, introduced the subject; Dr. A. W. Barton (Repton) and Mr. J. Clement Platt (Chadderton) opened the discussion. Dr. Barton addressed himself to the question, "Do we want general science?", and Mr. Platt to the question, "Is this the sort of general science we want ?" Both commended the report with minor qualifications: Dr. Barton considers that physics and chemistry are the best branches from which to learn scientific principles, and biology a good field for their application; Mr. Platt wants a better knitting of the different branches. Subsequent discussion took three main lines, which were stressed by many speakers: that the introduction set forth elearly, even brilliantly, the case for general science ; not a voice was raised against it. That the actual syllabus proposed was impractical (no speaker thought it possible to cover the ground suggested having regard to proper teaching method and due time for practical work, in four years at four periods a week; and some were emphatic that the broadsheets must be re-written); and that since four periods a week was an improperly small time for science, everything depended upon how the sub. committee's final report dealt with the rest of the time. Mr. Bryant replied wittily, and everyone awaits the final report with impatience; it can scarcely come in less than twelve months.

At the business meeting, Sir Cyril Ashfordmember of the Association since its formation in 1900-was elected president for next year. In succession to Dr. T. J. Baker (Birmingham), Mr. J. W. Cottingham (Barnsley), Mr. W. R. B. Brooks (Lowestoft) and Mr. W. J. R. Deeks (City of London), who retired from the Committee, the meeting elected Messrs. C. L. Byrant (Harrow), W. G. Rhodes (Firth Park, Sheffield), E. M. Rogers (Charterhouse) and H. P. Ramage (Gresham's, Holt). Mr. S. V. Brown (Liverpool Institute) was re-elected general secretary, Mr. B. M. Neville (William Ellis), honorary treasurer and Mr. R. E. Williams (Department of Education, (University of Oxford), annual meeting secretary.

Between five and six hundred science masters attended the meeting, and the University spared no pains to make them welcome; a University reception followed the presidential address.

\section{The U.S.S.R. Academy of Sciences and the Third Five-Year Plan}

\begin{abstract}
$\mathrm{T}$ HE Russian Academy of Sciences was founded in 1725 by Peter the Great as an "assembly of the best learned men" who were supposed to carry on research, to train young men of science, and to study the country's natural resources. Under the old regime, the Academy devoted most of its energies to abstract research, surveys of natural resources and the study of Asiatic languages. Its character did not change immediately after the Revolution and it remained out of touch with the economic needs of the country for some time. The change came in 1929 when the function of the Academy was defined as the direction of the whole volume of scientific knowledge towards the reconstruetion of national economy, and a number of members of the Communist Party, distinguished in various branches of technological science, were included in the Academy. In 1934 the Academy was made directly responsible to the Government of the U.S.S.R. and its headquarters were transferred from Leningrad to Moscow, in order to bring it into closer contact with central administrative bodies, particularly with the State Planning Commission. The headquarters of the Academy, its central administrative departments and its principal research institutes and laboratories are now in Moscow, where new buildings are being built to house the various sections.

Under its new constitution, adopted in November 1935, the aims and functions of the Academy are defined thus: First, the Academy is not merely a
\end{abstract}

centre for the passive registration of scientific facts, but also an active body for the development of scientific thought. Secondly, the Academy has to study and to develop world scientific achievements with the view of applying them to the work of construction. Thirdly, the Academy has to utilize the achievements of science to further the country's progress towards a classless order of society.

The Technical Section of the Academy was charged with the duty of seeing that the results of research were introduced into industry. It has to maintain contact not only with the research institutes and laboratories of the Academy itself, but also with the various commissariats and industrial enterprises. Among the groups now functioning under the Technical Section are those dealing with power, mining, technical physics, technical chemistry, technical mechanies, automatic processes and telemechanics.

Another function of the Academy is to study the natural resources and productive forces of the country, and to promote their rational utilization. For a number of years, the Council for the Study of the Natural Resources of the U.S.S.R. has been sending out expeditions for these purposes. Branches of the Academy have been established in various parts of the country to direct the work of prospecting and surveying. The first preliminary general survey of the geological, chemical and economic resources 